\title{
Purification and Characterization of a Polygalacturonase Produced by Wickerhamomyces anomalus
}

\author{
María Alicia Martos ${ }^{1 *}$, Ana Paula Butiuk ${ }^{1}$, Natalia Lorena Rojas ${ }^{2}$ and Roque Alberto \\ Hours $^{2}$ \\ ${ }^{1}$ Laboratorio de Microbiología de Alimentos y Biotecnología Dr. Fernando O. Benassi; Facultad de Ciencias \\ Exactas Químicas y Naturales; Universidad Nacional de Misiones; Misiones - Argentina. ${ }^{2}$ Centro de Investigación \\ y Desarrollo en Fermentaciones Industriales; Universidad Nacional de La Plata - CONICET; La Plata - Argentina
}

\begin{abstract}
The aim of this work was to study the purification and physicochemical properties of an endo-polygalacturonase $(P G)$ produced by Wickerhamomyces anomalus isolated from the citrus fruit peels. The enzyme was purified to homogeneity from the culture filtrate of $\mathrm{W}$. anomalus grown on the yeast nitrogen base medium with glucose as carbon and energy source and citrus pectin as inductor. After anion-exchange chromatography and gel filtration chromatography, PG activity was eluted as a single peak, yielding $21 \%$ of the original activity. After dialysis and cation-exchange chromatography, only one fraction with PG activity was obtained, recovering $56 \%$ of initial enzyme activity and 1.3-fold increase in specific activity. The molecular weight of the enzyme was estimated as 43 $k D a$ by the SDS-PAGE. The enzyme exhibited maximal activity at pH 4.2 and was stable over a pH range from 3.5 to 6.0 and up to $49^{\circ} \mathrm{C}$ for $10 \mathrm{~h}$. The $V_{\max }$ and $K_{m}$ values with polygalacturonic acid as substrate were 0.26 mmol/L.min and $0.173 \mathrm{mg} / \mathrm{mL}$, respectively. Cations such as $\mathrm{Cu}^{+2}, \mathrm{Fe}^{+3}, \mathrm{Mg}^{+2}, \mathrm{Mn}^{+2}$ and $\mathrm{Zn}^{+2}$ did not show any significant effect on $P G$ activity but $\mathrm{K}^{+}$and $\mathrm{Ca}^{+2}$ reduced it. The purified $P G$ was able to macerate cassava tissues.
\end{abstract}

Key words: Wickerhamomyces anomalus, polygalacturonase, purification, characterization

\section{INTRODUCTION}

Enzymes hydrolyzing the pectic substances are known as pectinolytic enzymes or pectinases. These enzymes are responsible for the degradation of pectic substances that occur as structural polysaccharides in the middle lamella and the primary cell walls of plant tissues. Based on their mode of action, these enzymes are classified as polygalacturonase (PG), pectin esterase (PE), pectin lyase (PL) and pectate lyase (PAL). PG, PL and PAL are depolymerizing enzymes, which split the $\alpha$-(1,4)-glycosidic bonds between galacturonic monomers in pectic substances either by the hydrolysis (PG) or by $\beta$-elimination (PL, PAL). PE catalyzes the de-esterification of the methoxyl group of pectin, forming pectic acid (Jayani et al. 2005; Tari et al. 2007).

Pectinases play a key role in food technology, mainly in the processing of fruit juices and wines and in the maceration of plant tissues (Croak and Corredig 2006; Nighojkar et al. 2006). Maceration is a process by which organized tissue is transformed into a suspension of intact cells by the action of pectinases, resulting in pulpy products used for nectar as baby foods and ingredient for diary products. For such purposes, only the intercellular cementing material that holds together the cells (protopectin) and some portion of primary plant cell walls should be removed without

*Author for correspondence: amartos@arnet.com.ar 
damage to adjacent secondary cell walls, to help avoid cell lysis, keeping the nutritional properties of food (Costa et al. 2007).

A pectinolytic yeast strain was isolated from the citrus fruit peels in the province of Misiones, Argentina and it was identified as Wickerhamomyces anomalus, re-classification of the species Pichia anomala (Kurtzman 2008; Martos et al. 2013a). This wild yeast strain, grown on a yeast nitrogen base medium with glucose and citrus pectin produced an endo-PG with maceration activity of vegetable tissues. The supernatant of $W$. anomalus was able to macerate cassava and potato tissues (Martos et al. 2013a, b). In view of the potential applicability of PG secreated by $W$. anomalus in food technology, the present work reports the purification and some relevant physicochemical properties of the enzyme.

\section{MATERIALS AND METHODS}

\section{Microorganism}

$W$. anomalus, isolated from the citrus fruit peels in the province of Misiones, Argentina (Martos et al. 2013a) was used in this study.

\section{Culture media}

$Y M$ medium contained $(\mathrm{g} / \mathrm{L})$ yeast extract (Sigma Chemical Co., St. Louis, Mo, USA) 5, tryptone (Difco-Becton Dickinson \& Co.,Sparks, MD, USA) 5, glucose (Britania, Buenos Aires, Argentina) 10, agar (Britania),15 and the $\mathrm{pH}$ was 5.0.

YNB medium contained $(\mathrm{g} / \mathrm{L})$ yeast nitrogen base (YNB, Difco) 6.7, glucose (Britania) 5, citrus pectin (Parafarm, Buenos Aires, Argentina) 5 and the $\mathrm{pH}$ was 5.0. Citrus pectin was washed with $70 \% \quad(\mathrm{v} / \mathrm{v})$ ethanol-HCl $(0.05 \mathrm{~N})$ solution to remove the soluble sugars (Cavalitto et al. 1996). All the components of media were autoclaved $\left(121^{\circ} \mathrm{C}, 15 \mathrm{~min}\right)$, except in the case of YNB solution, which was sterilized separately by filtration through a cellulosic filter paper $(0.22 \mu \mathrm{m}$, Sartorius).

\section{Enzyme production}

Five hundred millilitre Erlenmeyer flasks with 95 $\mathrm{mL}$ of YNB medium were inoculated with $5.0 \mathrm{~mL}$ of an appropriate dilution of a suspension of the microorganism $\left(\mathrm{OD}_{620}=0.96\right)$, grown in $\mathrm{YM}$ medium $\left(30^{\circ} \mathrm{C}, 24 \mathrm{~h}\right)$. The Erlenmeyer flasks were incubated at $30^{\circ} \mathrm{C}$ for $10 \mathrm{~h}$ on a rotary shaker at $180 \mathrm{rpm}$. The biomass was separated by centrifugation at $2350 \times g$ at $5^{\circ} \mathrm{C}$ for $10 \mathrm{~min}$. The culture medium supernatant, named enzymatic extract (EE), was frozen at $-18^{\circ} \mathrm{C}$ and used as source of extracellular enzyme (Martos et al. 2013a).

\section{Enzyme purification procedures}

The EE $(500 \mathrm{~mL})$ was concentrated $(2 \times)$ on a vacuum rotary evaporator at $38^{\circ} \mathrm{C}$. The resulting solution was lyophilized to dryness and resuspended $(5 \times)$ in sodium acetate buffer $($ AcB 0.2 $\mathrm{M}, \mathrm{pH}$ 5.0). The concentrated enzymatic extract (CEE) obtained was subject to two purification procedures (Procedure I and Procedure II). All the chromatographic steps were carried out on an Amersham FPLC system (ÄKTA FPLC-U900 Chromatographyc System, GE Healthcare). After each chromatographic step, fractions with PG activity were applied to a PD-10 desalting column (GE Healthcare) and then loaded onto a single well $10 \%$ SDS-PAGE minigel, in a Mighty Small II Unit (Hoefer SE 260, GE). Proteins were visualized by Coomassie Brilliant Blue G-250 staining (Smith 1984).

\section{Procedure I}

The CEE was desalted on a Sephadex G-25 gel filtration column (XK 16/100, GE Healthcare), equilibrated with $\mathrm{AcB}(0.2 \mathrm{M}, \mathrm{pH} 5.0)$. The column was eluted with the same buffer over 3.4 column volumes, at a flow rate of $2 \mathrm{~mL} / \mathrm{min}$, during $1.5 \mathrm{~h}$. Fractions of $3.0 \mathrm{~mL}$ were collected and those exhibiting PG activity were pooled, freeze-dried, re-suspended in AcB and poured over a Q Sepharose FF anion-exchange column (XK 26/20, GE Healthcare). The column was washed with $\mathrm{AcB}$ and the bound proteins were then eluted with a linear gradient of $\mathrm{NaCl}(0-0.5 \mathrm{M})$ in the same buffer over 7.5 column volumes at a flow rate of $1.5 \mathrm{~mL} / \mathrm{min}$ for $3 \mathrm{~h}$. Fractions $(3.0 \mathrm{~mL})$ were collected and analyzed for PG activity. Fractions with PG activity were pooled, concentrated by lyophilization and applied to a PD-10 desalting column (GE Healthcare) equilibrated with the same buffer. The eluate was subsequently loaded onto a Sephacryl S-100 gel filtration column (XK 16/100, GE Healthcare) equilibrated with $\mathrm{AcB}(0.2 \mathrm{M}, \mathrm{pH} 5.0)$. The bound proteins were eluted at a flow rate of $1.5 \mathrm{~mL} / \mathrm{min}$ and fractions of $1.5 \mathrm{~mL}$ were collected, during 150 min, over 1.9 volumes of column. Fractions with 
PG activity were pooled, concentrated by lyophilization and kept refrigerated until use.

\section{Procedure II}

The CEE $(18 \mathrm{~mL})$ was dialyzed overnight at $5^{\circ} \mathrm{C}$ against buffer $\mathrm{AcB}(0.2 \mathrm{M}, \mathrm{pH} 5.0)$. After dialysis, the solution was freeze-dried, re-suspended in AcB and loaded onto a SP-Sepharose FF cationexchange column (XK 26/20, GE Healthcare) equilibrated with the same buffer. The bound proteins were then eluted with a linear gradient of $\mathrm{NaCl}(0-0.5 \mathrm{M})$ over four column volumes at a flow rate of $3.0 \mathrm{~mL} / \mathrm{min}$ during $150 \mathrm{~min}$. Fractions of $6.0 \mathrm{~mL}$ were collected and those with PG activity were pooled, concentrated by lyophilization and kept refrigerated until use.

\section{Enzyme characterization}

Molecular weight

The molecular weight of the purified enzyme was determined by the SDS-PAGE, using a low molecular weight marker (14.5 a $94 \mathrm{kDa}, \mathrm{GE}$ Healthcare).

Effect of $p H$ on the purified polygalacturonase activity and stability

The effect of $\mathrm{pH}$ on the purified PG activity was determined by incubating the reaction mixture at $\mathrm{pH}$ values ranging from 2.6 to 6.0 under the standard enzyme assay conditions. The $\mathrm{pH}$ stability of the enzyme was evaluated by measuring the residual activity under standard enzyme assay conditions after incubating the pure enzyme without substrate for $24 \mathrm{~h}$ at $5^{\circ} \mathrm{C}$ at various $\mathrm{pH}$ from 2.6 to 7.0. The buffer employed in these measurements was citric phosphate buffer (CPB, $0.1 \mathrm{M}$ citric acid and $0.2 \mathrm{M} \mathrm{Na}_{2} \mathrm{HPO}_{4}$ ). The $\mathrm{pH}$ was initially adjusted to $\mathrm{pH} 5.0$ with $\mathrm{NaOH}$ and then recalibrated to the desired $\mathrm{pH}$ with $\mathrm{HCl}$ or $\mathrm{NaOH}$. All the experiments were conducted in triplicate and the results showed the mean values of the activities.

\section{Thermal stability of the purified $P G$}

For the determination of the thermal stability, the enzyme was pre-incubated over a range of temperature from $37^{\circ} \mathrm{C}$ to $60^{\circ} \mathrm{C}$ in the $\mathrm{CPB}$ at $\mathrm{pH}$ optimum. Residual activity was measured during $10 \mathrm{~h}$, under the standard enzyme assay conditions. All the experiments were conducted in triplicate and the results showed the mean values of the activities.

\section{Enzyme kinetics}

The Michaelis constant $\left(\mathrm{K}_{\mathrm{m}}\right)$ and $\mathrm{V}_{\max }$ values of purified PG were determined from LineweaverBurk plots of enzyme activity measured under the standard enzyme assay conditions with polygalacturonic acid (PGA; Sigma) as the substrate at concentrations between 0.05 to $2.5 \mathrm{~g} / \mathrm{L}$ in $\mathrm{BCP}$ at $\mathrm{pH}$ optimum.

Influences of metal ions on the purified $P G$ activity Before the assay, the enzyme solution was dialized in order to remove all the interfering substances. The effect of cations such as $\mathrm{Cu}^{+2}, \mathrm{Ca}^{+2}, \mathrm{Fe}^{+3}, \mathrm{~K}^{+}$, $\mathrm{Mg}^{+2}, \mathrm{Mn}^{+2}$ and $\mathrm{Zn}^{+2}$ on enzyme activity was tested in the reaction medium under the standard enzyme assay conditions.

\section{Analytical techniques}

Enzyme activity assays

PG activity was assayed by measuring the reducing groups released after incubation of reaction medium at $30^{\circ} \mathrm{C}$ for $10 \mathrm{~min}(\mathrm{pH} \mathrm{5.0)}$ by dinitrosalicylic acid method using PGA as the substrate (Miller 1959). A calibration curve was made with galacturonic acid (GA, Sigma) as standard. One unit of $\mathrm{PG}$ was defined as the amount of enzyme which releases $1 \mu \mathrm{mol}$ of GA per minute.

\section{Protein estimation}

Protein concentrations were determined by the Bradford method using bovine serum albumin (Sigma) as standard (Bradford 1976).

\section{Assay of maceration activity}

To evaluate the maceration capacity of the purified PG on cassava tissues, cassava was peeled and cut into pieces (3-4 $\mathrm{mm}$ on each side), placed in Petri dishes, submerged in a purified $\mathrm{PG}$ solution in $\mathrm{AcB}(0.2 \mathrm{M}, \mathrm{pH} 5.0)$ and incubated at $30^{\circ} \mathrm{C}$ for 2 h. Maceration activity was estimated from the loss of coherence of tissue and by microscopic observations. Blanks were prepared with heatdenatured enzyme.

\section{RESULTS AND DISCUSSION}

\section{Enzyme purification}

The results of the purification process of PG by Procedure I are summarized in Table 1. Elution profiles of PG on Q Sepharose FF anion-exchange 
column and Sephacryl S-100 gel filtration column are shown in Figures 1 and 2, respectively.

Table 1 - Summary of $W$. anomalus PG purification by Procedure I.

\begin{tabular}{lcccc}
\hline $\begin{array}{c}\text { Purification } \\
\text { step }\end{array}$ & $\begin{array}{c}\text { Total } \\
\text { activity } \\
(\mathbf{U})\end{array}$ & $\begin{array}{c}\text { Total } \\
\text { protein } \\
(\mathbf{m g})\end{array}$ & $\begin{array}{c}\text { Specific } \\
\text { activity } \\
\text { (U/mg } \\
\text { protein) }\end{array}$ & $\begin{array}{c}\text { Recovery } \\
(\%)\end{array}$ \\
\hline CEE $(10 \times)$. & 731.3 & 4.93 & 148 & 100 \\
Sephadex G-2 & 488 & 2.604 & 188 & 66 \\
Sepharose Q & 324.5 & 1.26 & 258 & 44 \\
Sephacryl S-100 & 159 & ND & ND & 21 \\
\hline
\end{tabular}

ND: not detected, CEE: concentrated enzymatic extract.

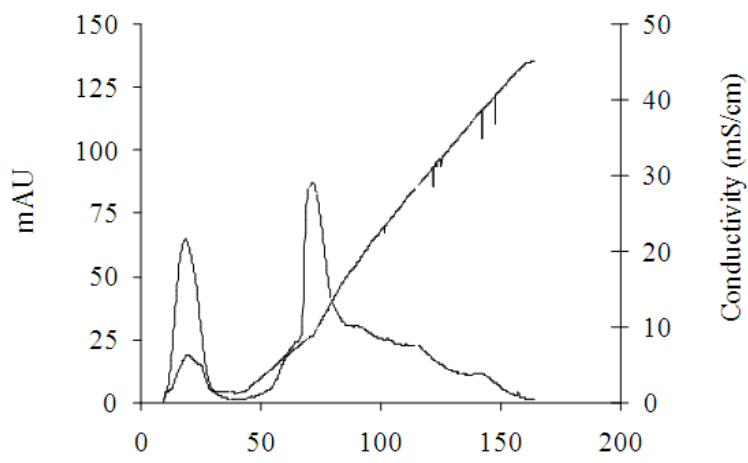

Elution volume $(\mathrm{mL})$

Figure 1 - Elution profile of $W$. anomalus $\mathrm{PG}$ on $\mathrm{Q}$ Sepharose anion-exchange column (XK 26/20), equilibrated with AcB. Elution of bound proteins with a linear gradient of $\mathrm{NaCl}$ (0 - $0.5 \mathrm{M})$ in $\mathrm{AcB}$, column volume: 7.5 , flow rate: $1.5 \mathrm{~mL} / \mathrm{min}$, time of elution: $180 \mathrm{~min}$.

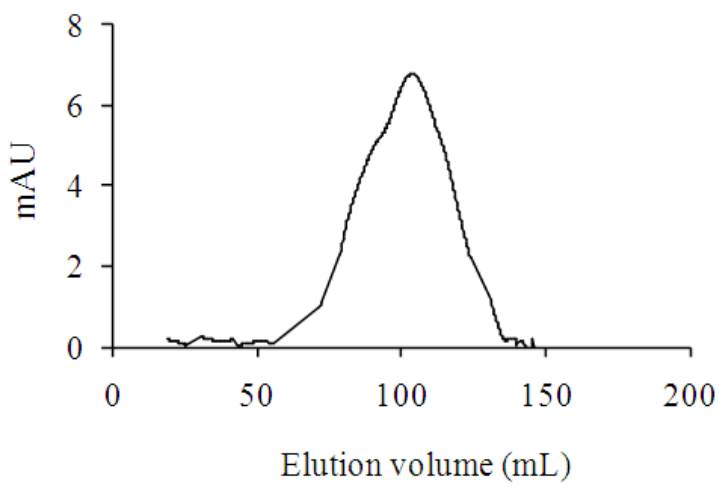

Figure 2 - Elution profile of $W$. anomalus $\mathrm{PG}$ on Sephacryl S-100 gel filtration column (XK 16/100), equilibrated with $\mathrm{AcB}(0.2 \mathrm{M}, \mathrm{pH}$ 5.0). Elution of proteins with $\mathrm{AcB}$, column volume: 1.9 , flow rate: $1.5 \mathrm{~mL} / \mathrm{min}$, time of elution: $150 \mathrm{~min}$.
From Sephadex G-25 column, a fraction 6-13, free of salts, was collected, recovering $66 \%$ of initial enzyme activity (Table 1). During anion-exchange chromatography, the protein with PG activity did not bind to Q-Sepharose FF column; others contaminating proteins were eluted at high ionic strength (Fig. 1). In this step, $44 \%$ of the initial enzyme activity was recovered (Table 1). After the subsequent purification step using Sephacryl S100 gel filtration column, PG activity was eluted as a single peak yielding $21 \%$ of the original PG activity (Fig. 2). A summary of the purification process of PG by Procedure II is presented in Table 2. Elution profiles of PG on SP-Sepharose FF cation-exchange column is shown in Figure 3. Figure 4 shows the SDS-PAGE of proteins obtained during the different steps of purification.

Table 2 - Summary of W.anomalus PG purification process by Procedure II.

\begin{tabular}{lcccc}
\hline $\begin{array}{c}\text { Purification } \\
\text { step }\end{array}$ & $\begin{array}{c}\text { Total } \\
\text { activity } \\
(\mathbf{U})\end{array}$ & $\begin{array}{c}\text { Total } \\
\text { protein } \\
(\mathbf{m g})\end{array}$ & $\begin{array}{c}\text { Specific } \\
\text { activity } \\
\text { (U/mg } \\
\text { protein) }\end{array}$ & $\begin{array}{c}\text { Recovery } \\
(\%)\end{array}$ \\
\hline CEE & 1.341 & 8.12 & 165 & 100 \\
Dialysis & 903 & 5.06 & 179 & 67 \\
SP-Sepharose & 746 & 3.33 & 224 & 56 \\
\hline
\end{tabular}

CEE: concentrated enzymatic extract.

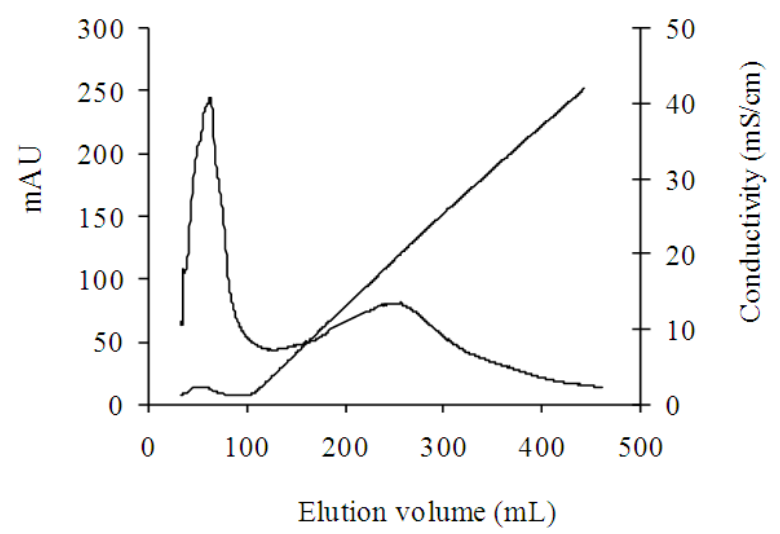

Figure 3 - Elution profile of $W$. anomalus PG on SPSepharose cation-exchange column (XK 26/20), equilibrated with AcB (0.2 M, pH 5.0). Elution of proteins with linear gradient of $\mathrm{NaCl}(0-0.5 \mathrm{M})$ in $\mathrm{AcB}$, column volume: 4, flow rate: $3 \mathrm{~mL} / \mathrm{min}$, time of elution: 150 min. 


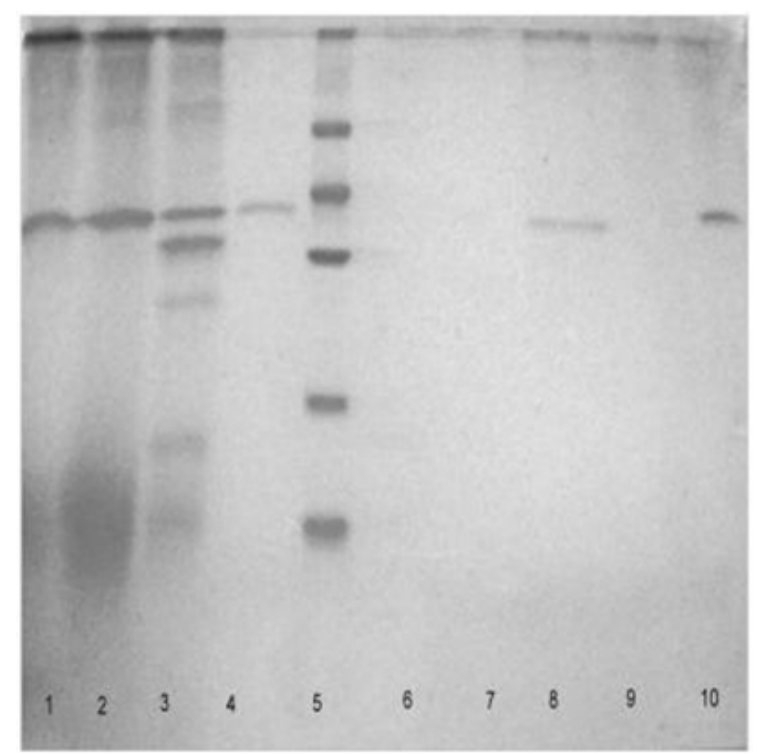

Figure 4 - SDS-PAGE with Coomassie staining of the purification steps of $W$. anomalus PG. Lane 1: concentrated enzymatic extract (CEE). Lane 2: after dyalisis. Lane 3: after desalted on a Sephadex G-25 column. Lane 4: after Q Sepharose chromatography. Lane 5: low molecular weight marker. Lane 6: after Q Sepharose chromatography (without PG activity). Lane 7: after Sephacryl S-100 chromatography (fraction 26-40, without PG activity). Lane 8: after Sephacryl S-100 chromatography (fraction 50-70). Lane. 9: after SP-Sepharose chromatography (fraction 7-13), without activity. Lane 10: after SPSepharose chromatography (fraction 26-70).

After dialysis, $67 \%$ of the initial enzymatic activity was recovered (Table 2). From cationexchange chromatography a fraction (33-54) with PG activity was obtained, recovering $56 \%$ of initial enzyme activity and 1.3-fold increase in PG specific activity (Fig. 3). The protein in lane 4 (after Q Sepharose chromatography), lane 8 (after Sephacryl S-100 chromatography) and lane 10 (after SP-Sepharose chromatography) showed a single band on $10 \%$ SDS-PAGE (Fig. 4). PG produced by $S$. cerevisiae CECT1389, grown on YNB medium composed of glucose and PGA, was purified in a single step by size-exclusion chromatography from the culture filtrate (Blanco et al. 1994). Pedrolli et al. (2009) reported that pectic enzymes purifications were performed mainly by the chromatographic techniques. A. giganteus $\mathrm{PG}$ was purified after two simple steps: protein precipitation and anion-exchange chromatography. Most of methods for purifying the fungal and bacterial PGases that have been published are associated with considerable enzyme losses, mainly caused by the relatively high number of steps required during the purification process (Pedrolli and Carmona 2010). The purification process described for $W$. anomalus in the present study, using procedure II, could be useful for future industrial scale application. By means of this process, high yields of the enzyme could be obtained in few stages.

\section{Molecular weight}

The SDS-PAGE revealed an apparent molecular weight of $43 \mathrm{kDa}$ for $W$. anomalus PG (Fig.4). It has been reported that the molecular weight of PGases from different sources usually ranged between 40 and $60 \mathrm{kDa}$ (Jayani et al. 2005; Pedrolli and Carmona 2010).

\section{Effect of pH on PG activity and stability}

The effect of $\mathrm{pH}$ on purified PG activity is shown in Figure 5. Figure 6 represents the values of enzymatic residual activity after incubating the enzyme at different $\mathrm{pH}$ for $24 \mathrm{~h}$ at $5^{\circ} \mathrm{C}$.

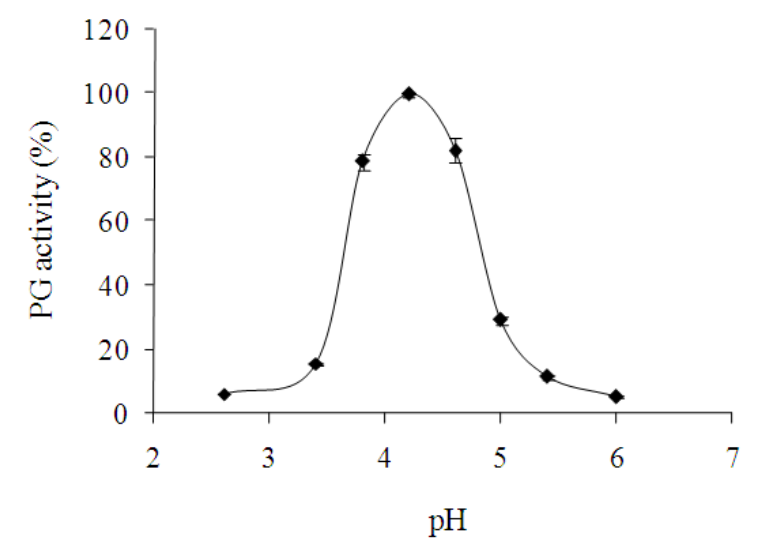

Figure 5-Effect of $\mathrm{pH}$ on purified $\mathrm{PG}$ activity produced by $W$. anomalus. PG activity was determined as a percentage of the enzyme activity under standard enzyme conditions.

PG secreted by $W$. anomalus exhibited maximal activity at $\mathrm{pH} 4.2$ (Fig. 5). Figure 6 showed that pure enzyme was stable at a $\mathrm{pH}$ range from 3.5 to 6.0 , after incubation time of $24 \mathrm{~h}$ at $5^{\circ} \mathrm{C}$. The analysis of variance revealed no significant differences between these values $(\mathrm{p}<0.05)$. The enzyme retained $86 \%$ of its activity at $\mathrm{pH}$ 7.0. The optimum $\mathrm{pH}$ for a purified $\mathrm{PG}$ of $S$. cerevisiae CECT1389 was 5.5 and this enzyme was stable in 
the $\mathrm{pH}$ range of 4.5 to 6.0 (Blanco et al. 1994). Blanco et al. (1999) reported that yeasts PGases exhibited an optimum $\mathrm{pH}$ in the acidic region between 3.5 and 5.5. The optimum $\mathrm{pH}$ for $\mathrm{PG}$ produced by $S$. cerevisiae UCLMS-39 after a purification process was 3.5 (Fernández-González et al. 2004).

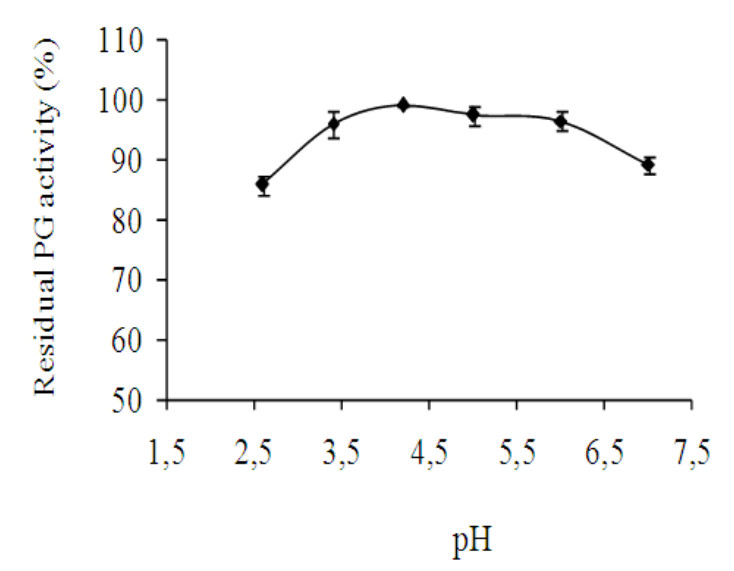

Figure 6 - Effect of $\mathrm{pH}$ on purified PG stability produced by $W$. anomalus. PG activity was determined as a percentage of the enzyme activity under standard enzyme conditions.

\section{Thermal stability of PG}

The effect of temperature on the purified PG stability produced by $W$. anomalus is shown in Figure 7.

Figure 7 showed that in the absence of substrate, purified PG was stable at 37,43 and $49^{\circ} \mathrm{C}$ for $10 \mathrm{~h}$ of incubation at optimum $\mathrm{pH}$. The analysis of variance revealed no significant differences between these values $(\mathrm{p}<0.05)$. At $55^{\circ} \mathrm{C}$, the enzymatic activity decreased and retained only $37 \%$ of the initial activity after $15 \mathrm{~min}$ of incubation. The thermal stability of PG produced by $W$. anomalus was similar to that reported for PGases from others yeasts such as $S$. cerevisiae IM1-8b and S. cerevisiae 1389, which were quite stable in the $20-50^{\circ} \mathrm{C}$ temperature range but were inactivated $(80 \%)$ within $5 \mathrm{~min}$ at $55^{\circ} \mathrm{C}$ (Blanco 1997). Two PGases of Cryptococcus sp. (named p36 and p40) remained stable up to $40^{\circ} \mathrm{C}$ for 30 min (Miura et al. 2001). The optimum temperature for PG produced by $S$. cerevisiae UCLMS-39 was $50^{\circ} \mathrm{C}$; higher from this temperature, the activity gradually decreased (Fernandez-Gonzalez et al. 2004). The knowledge of enzyme stability is important to maintain the desired level of enzyme activity over a long period of time and improve its stability for an efficient application in an industrial process (Martins et al. 2007). Besides after any application, the enzyme has to be inactivated, so the knowledge of thermal inactivation has great importance too (Tari et al. 2008).

Some authors reported that during the purification procedure, some protein stabilizing factors might be lost (Naidu and Panda 2003; Martins et al. 2007; Pedrolli and Carmona 2010). Data published previously with crude PG from $W$. anomalus obtained in YNB medium showed that enzyme maintained $78 \%$ of its residual activity of after 30 min at $55^{\circ} \mathrm{C}$ (Martos et al. 2013b). These results suggested that PG lost stability after the purification process.

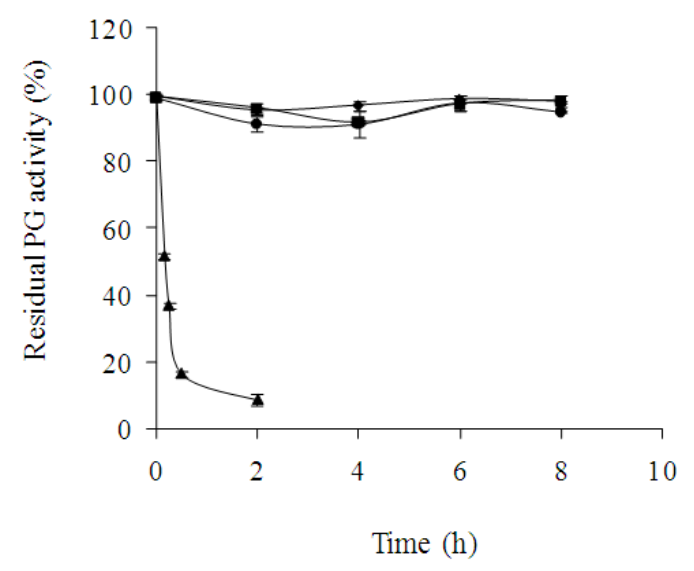

Figure 7-Effect of temperature on purified PG stability produced by W. anomalus. Symbol: $\$ 37^{\circ} \mathrm{C}$, $43^{\circ} \mathrm{C}, \bullet 49^{\circ} \mathrm{C}, \boldsymbol{\Delta} 55^{\circ} \mathrm{C}$. PG activity was determined as a percentage of the enzyme activity under standard enzyme conditions.

\section{Kinetic parameters}

Kinetic parameters such as $\mathrm{V}_{\max }$ and $\mathrm{K}_{\mathrm{m}}$ were determined from the regression lines of Lineweaver-Burk plots. The $\mathrm{V}_{\max }$ and $\mathrm{K}_{\mathrm{m}}$ values obtained for the PGA were $0.26 \mathrm{mmol} / \mathrm{L}$.min and $0.173 \mathrm{mg} / \mathrm{mL}\left(\mathrm{R}^{2}: 0.901\right)$, respectively. Similar $\mathrm{K}_{\mathrm{M}}$ values have been described for several yeast strains, such as $0.57,0.09,0.62$ and $0.59 \mathrm{mg} / \mathrm{mL}$ for PGases produced by Cryptococcus albidus (Federichi 1985), G. lactis (Blanco et al. 1994), Saccharomyces pastorianus and Saccharomyces cerevisiae IMI-8b (Gummadi and Panda 2003), respectively. 


\section{Effects of various cations on PG activity}

The effects of various cations on purified PG activity is shown in Figure 8.

$\mathrm{Cu}^{+2}, \mathrm{Fe}^{+3}, \mathrm{Mg}^{+2}, \mathrm{Mn}^{+2}$ and $\mathrm{Zn}^{+2}$ did not show any significant effect on the purified PG activity under the assay conditions, whereas the residual PG activity was 67 and $56 \%$ in the presence of $\mathrm{Ca}^{+2}$ and $\mathrm{K}^{+}$, respectively. It was reported that PGases tended to undergo changes in their physical and chemical properties in the presence of some ions. Therefore, it was necessary to test the effects of a number of representative cations in the reaction medium on PG activity (Miura et al. 2001).

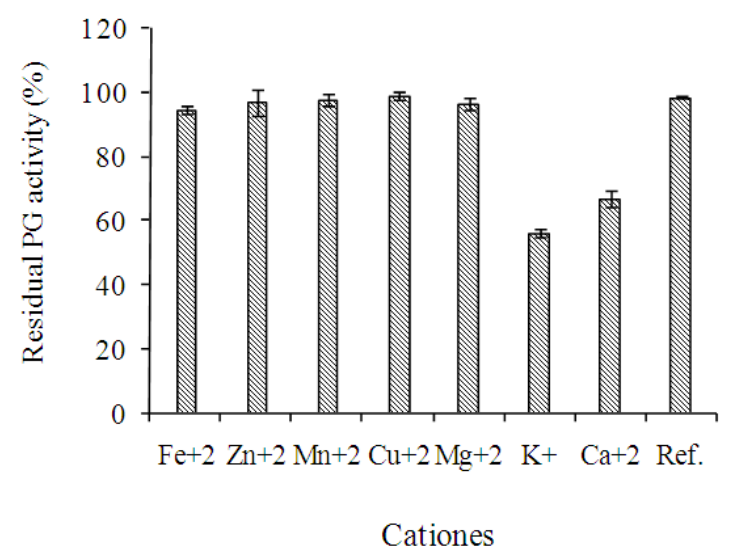

Figure 8 - Effects of cations on purified PG activity produced by $W$. anomalus. PG activity was determined as a percentage of the enzyme activity under standard enzyme conditions.

\section{Assay of maceration activity}

Purified PG was able to macerate the cassava tissue as shown by the loss of coherence of the tissue. Microscopic examination of the maceration product showed single cells. These results confirmed the maceration capacity of PG as it was reported previously with the supernatant of $W$. anomalus (Martos et al. 2013a).

\section{CONCLUSIONS}

Polygalacturonase from the culture supernatant of $W$. anomalus, grown on YNB medium with glucose and pectin, was efficiently purified using a two-step procedure with a high recovery (dialysis and cation-exchange chromatography). PG exhibited an optimum $\mathrm{pH}$ in the acidic region, a high stability over a large $\mathrm{pH}$ range and was stable up to $50^{\circ} \mathrm{C}$, suited to most fruit and vegetable processing applications. These properties suggested that this PG could be a potential candidate for different applications in food industry, mainly in the maceration of cassava tissues of regional interest in the province of Misiones, Argentina.

\section{REFERENCES}

Blanco P, Sieiro C, Diaz A, Villa TG. Production and partial characterization of an endopolygalacturonase from Saccharomyces cerevisiae. Can J Microbiol. 1994; 40: 974-977.

Blanco P, Sieiro C, Diaz A, Villa TG. Differences between pectic enzymes produced by laboratory and wild-type strains of Saccharomyces cerevisiae. World J Microbiol Biotechnol. 1997; 13:711-712.

Blanco P, Sieiro C, Villa TG. Production of pectic enzymes in yeasts. Mini Review. FEMS Microbiol Lett. 1999; 175: 1-9.

Bradford MM. A rapid and sensitive method for the quantification of microgram quantities of protein utilizing the principle of protein-dye binding. Anal Biochem. 1976; 72:248-254.

Cavalitto SF, Arcas JA, Hours RA. Pectinase production profile of Aspergillus foetidus in solid state cultures at different acidities. Biotechnol Lett. 1996; 18: 251-256.

Costa JAV, Colla E, Magagnin G, Oliveria dos Santos L, Vendruscolo M, Bertolin TE. Simultaneous amyloglucosidase and exo-polygalacturonase production by Aspergillus niger using solid-state fermentation. Braz Arch Biol Technol. 2007; 50 (5): 759-766.

Croak S, Corredig M. The role of pectin in orange juice stabilization: Effect of pectin methylesterase and pectinase activity on the size of cloud particles. Food Hydrocolloid. 2006; 20:961-965.

Federici F. Production, purification and partial characterization of an endopolygalacturonase from Cryptococcus albidus var. albidus. Antonie Van Leeuwenhoek. 1985; 51:139-150.

Fernández González M, Úbeda JF, Vasudevan TG, Cordero Otero RR, Briones AI. Evaluation of polygalacturonase activity in Saccharomyces cerevisiae wine strains. FEMS Microbiol Lett. 2004; 237: 261-266.

Gummadi SN, Panda T. Purification and biochemical properties of microbial pectinases: a review. Process Biochem. 2003; 38 (7): 987-996.

Jayani RS, Saxena S, Gupta R. Microbial pectinolytic enzymes: A review. Process Biochem. 2005; 40: 2931-2944. 
Kurtzman CP, Robnett CJ, Basehoar-Powers E. Relationships among species of Pichia, Issatchenkia and Williopsis determined from multigene phylogenetic analysis and the proposal of Barnettozyma gen. nov., Lindnera gen. nov. and Wickerhamomyces gen. nov. FEMS Yeast Res. 2008; 8: 939-954.

Martins ES, Silva D, Leite RS, Gomes E. Purification and characterization of polygalacturonase produced by thermophilic Thermoascus aurantiacus CBMAI756 in submerged fermentation. Antonie Van Leeuwenhoek. 2007; 91: 291-299.

Martos MA, Zubreski ER, Combina M, Garro OA, Hours RA. Isolation of a yeast strain able to produce a polygalacturonase with maceration activity of cassava tissues. Food Sci Technol. 2013a; 33(2): 332-338.

Martos MA, Zubreski ER, Garro OA, Hours RA. Production of Pectinolytic Enzymes by the Yeast Wickerhanomyces anomalus Isolated from Citrus Fruits Peels. Biotechnol Res Int. 2013b; 1:1-7.

Miller GL. Use of dinitrosalicylic acid reagent for determination of reducing sugar. Anal Chem. 1959; 31: 426-428.

Miura T, Abe F, Inoue A, Usami R, Horikoshi K. Purification and characterization of novel extracellular endopolygalacturonases from a deep-sea yeast, Cryptococcus sp. $\mathrm{N}^{\mathrm{o}} 6$, isolated from the Japan Trench. Biotechnol Lett. 2001; 23:1735-1739.

Naidu GSN, Panda T. Studies on $\mathrm{pH}$ and thermal inactivation of pectolytic enzymes from Aspergillus niger. Biochem Eng J. 2003; 16:57-67.
Nighojkar S, Phanse Y, Sinha D, Nighojkar A, Kumar A. Production of polygalacturonase by immobilized cells of Aspergillus niger using orange peel as inducer. Process Biochem. 2006; 41:1136-1140.

Pedrolli DB, Carmona EC. Purification and characterization of the exopolygalacturonase produced by Aspergillus giganteus in submerged cultures. J Ind Microbiol Biotechnol. 2010; 37:567573.

Pedrolli DB, Monteiro AC, Gomes E, Carmona EC. Pectin and pectinases production, characterization and industrial application of microbial pectinolytic enzymes. Open Biotechnol J. 2009; 3:9-18.

Smith BJ. Quantification of proteins on polyacrylamide gels. Methods Mol Biol. 1984; 1:119-125.

Tari C, Dogan N, Gogus N. Biochemical and thermal characterization of crude exo-polygalacturonase produced by Aspergillus sojae. Food Chem. 2008; 111(4): 824-829.

Tari C, Gögus N, Tokatli F. Optimization of biomass, pellet size and polygalacturonase production by Aspergillus sojae ATCC 20235 using response surface methodology. Enzyme Microbial Technol. 2007; 40: 1108-1116. 